\title{
Moderate Muslim Characters in The Quran and Its Implementation in Islamic Religious Education Learning in Public Universities
}

\author{
Sari Narulita \\ Islamic Education Departement, Faculty of Social Science, State University of Jakarta \\ Email: Sari-narulita@unj.ac.id \\ Pandu Hyangsewu \\ Sociology Education Departement, Faculty of Social Science Education, Indonesian \\ Email: hyangsewu@upi.edu
}

\section{Adimin Diens}

PAI Sub-Directorate at Public Universities, Ministry of Religion, of The Republic Indonesia

\begin{abstract}
Actions of radicalism and terrorism have hurt Muslims and placed them at fault. The teachings of jihad in Islam are often the target of accusations of being the leading cause of violence in the name of religion. Many Islamic teachings direct a Muslim to be moderate. This article explains the verses and hadiths related to Moderate Islam's character and describes the implementation process in PAI learning in public universities. This research is qualitative research by reviewing the verses of the Quran and hadith and observations on the implementation process through Islamic learning in several universities on the island of Java. The results show that the characteristics of moderate Muslims in the Quranic hadith lead to Muslims who can balance their attitudes and views. At the same time, the implementation process is realized through the PAI curriculum, which contains Islamic moderation values, supported by moderate lecturers, which directs students to understand Islamic teachings textually and contextually.
\end{abstract}

Keywords: Moderate Muslim, Quran, IRE

\begin{abstract}
Abstrak
Aksi Radikalisme dan Terorisme yang mengatasanamakan Islam telah memberikan dampak negatif bagi Umat Islam dan dan menempatkannya sebagai pihak yang dipersalahkan. Ajaran jihad dalam islam, kerapkali dijadikan sasaran tuduhan sebagai penyebab utama terjadinya kekerasan yang mengatasnamakan agama. Kenyataannya, ajaran Islam banyak mengarahkan seorang muslim untuk menjadi seseorang yang moderat. Artikel ini bertujuan memaparkan tentang ayat dan hadis terkait dengan karakter Islam Moderat; juga menggambarkan proses Implementasinya pada Pembelajaran PAI di Perguruan Tinggi Umum. Penelitian ini adalah penelitian kualitatif dengan mengulas ayat Quran dan hadis; serta observasi atas proses implementasinya melalui Pembelajaran Islam di beberapa Perguruan Tinggi di Pulau Jawa. Hasil penelitian menunjukkan bahwa karakteristik Muslim moderat dalam Quran hadis mengarah pada muslim yang mampu menyeimbangkan sikap dan pandangannya; sedang proses implementasinya diwujudkan melalui kurikulum PAI yang memiliki muatan nilainilai moderasi Islam, yang ditunjang oleh dosen yang moderat, yang mengarahkan mahasiswa untuk mampu memahami ajaran Islam secara tekstual dan juga kontekstual.
\end{abstract}

Kata Kunci: Muslim Moderat, Quran, PAI 


\section{A. Introduction}

Indonesia is a country with the largest population globally and is a country with a religious community. Research in 2020 revealed that Indonesia is in the top rank or is the most religious country of all existing governments and even beats Middle Eastern countries. As many as $96 \%$ of Indonesian respondents think one must believe in God to be moral, and 98\% consider religion necessary in their lives. Compared to previous years, the level of trust among Indonesians in God and religion is also not much different. During 2007-2019, the belief that faith makes a person moral was shared by 96-99\% of respondents. These make Indonesia occupy the top level as a country with the most religious citizens. The results of this study indicate that religious teachings are the primary consideration in doing something.

Understanding and implementing Islamic teachings is a necessity for the Muslim community. But when understanding is accompanied by the belief that being different is wrong and deserves to be fought, then this is where the problem lies. Islamic teachings seem to be understood only textually. Muslims who understand Islamic teaching textual are referred to as conservative groups. Bruinessen defines conservative Islam as a school of thought that rejects liberal and progressive reinterpretation of Islamic teachings. This school tends to maintain a standardized interpretation and social system. Conservative Islam is different from fundamentalist Islam. Fundamentalist Islam is more defined as a movement or flow that invites Muslims to return to the primary sources of Islamic teachings, the Qur'an and hadith. It is also different from the Islamist movement, which is defined as a movement that supports the idea of Islam as a political system and struggles to establish an Islamic state. ${ }^{1}$

Religious conservatism is generally motivated by an understanding of religion based on textualism and scripturalism. Textualism assumes that the primary source of religious teachings is religious texts. The textualists tend to reject the rational-contextual approach in understanding spiritual teachings. For them, textual truth is a non-negotiable fixed price. Scripturalism tends to interpret religious texts literally and ignore the sociohistorical context of the text. Even more fatal, scripturalists are often arrogant by considering the results of their interpretation as the product of the most authoritative thoughts. They infrequently force other groups to submit to the truth values they profess.

\footnotetext{
${ }^{1}$ Martin van Bruinessen, Contemporary Developments in Indonesian Islam Explaining the "Conservative Turn (Singapore: ISEAS, 2013).
} 
Coercion accompanied by violence is what then makes a person a radical. Radicalism and Terrorism in Islam have harmed Muslims and placed them at fault. The teachings of the term Jihad in Islam are often the target of accusations of being the leading cause of violence in the name of religion. The purification of Islam became a form of the legitimacy of coercion is a factor in the growth of radical understanding. One of the teachings of Islam that tends to be interpreted rigidly is related to the term Jihad which is only narrowed down to war against infidels, non-religious people. On that basis, Islam seems to understand that to become a true Muslim can only be done by destroying the infidels. $^{2}$

Religious conservatism is considered not a problem as long as it does not lead to extremism. ${ }^{3}$ Conservatism becomes harmful when it turns into ultra-conservatism, leading to exclusivism, radicalism, self-closure from change, resistance to change, and even coercion on others with difficulty accepting/listening to the truth or differences. This understanding becomes even more phenomenal when conservatism and exclusivism meet political interests. Thus religion, which was initially meant to solve problems, actually creates problems. ${ }^{4}$ Most Muslims in Indonesia are well known for their moderate faith, mixing and matching textual verses with contextualist understanding. Moderation of Islam in Indonesia is realized through two major Islamic organizations in Indonesia, Muhammadiyah and Nahdlatul Ulama, which have consistently shown moderate Islam. ${ }^{5}$ Syafi'I Maarif revealed that NU and Muhammadiyah have been working together for a long time to demonstrate a tolerant, peaceful Islam, being friendly to everyone, even to non-believers. ${ }^{6}$

Moderate Islam in Indonesia is manifested by Islam Nusantara, which is identical to Nahdlatul Ulama and the progressive Islam of Muhammadiyah. Moderate Islam has principles but still respects differences. No debate coachmen and fight muscles based on unclear truth and no assumption that their direction is the most correct so that the others must be wrong.

\footnotetext{
2 Emna Laisa, "Islam Dan Radikalisme," Islamuna 1, no. 1 (2014): 1-18.

3 Anom Prihantoro, Mahfud: Konservatisme beragama tidak bermasalah. Antaranews.com, 28 Desember 2018. https://www.antaranews.com/berita/782286/mahfud-konservatisme-beragama-tidak-bermasalah

${ }^{4}$ Eva Mazrieva. Risalah Jakarta; Catatan Penting akhir tahun. https://www.voaindonesia.com/a/risalahjakarta-catatan-penting-akhir-tahun-/4722470.html

5 Zakiyah Darajat, Muhammadiyah dan NU: Penjaga Moderatisme Islam di Indonesia, Hayula: Indonesian $\begin{array}{lllll}\text { Journal of Multidisciplinary } \quad \text { Islamic } & \text { Studies, } & 1(1), & 2017, & 79-94\end{array}$ https://doi.org/https://doi.org/10.21009/hayula.001.1.05

${ }^{6}$ A Wahid, Ilusi negara Islam: ekspansi gerakan Islam transnasional di Indonesia. Jakarta: Wahid Institute, 2009
} 
. The internalization of Islamic moderation values will be more effective through education. The education path is more integrative and comprehensive. It has a variety of aspects or materials that are interrelated. The most potent weapon in dealing with a pluralistic society that can be radical is moderate and inclusive Islamic education. Islamic moderation education can prevent students from behaving radically in attitude and thought. The output of Islamic educational institutions with the existence of moderation-based Islamic education can have implications for the understanding of all Muslims to accept all forms of differences in religion and respect other beliefs.

But how does the Quran direct the moderate Muslim character, and how is it implemented in Islamic Religious Education Learning in Higher Education? This article tries to explain it briefly and concisely.

\section{B. Research Methode}

The research uses a descriptive qualitative approach where the researcher uses data, both in document searches, observations, questionnaires, and articles in various journals to support this research. The primary data in this study are the Quran and Hadith, which discuss the term 'moderation', and the Semester Learning Plan of Islamic Religious Education (IRE) Learning, which adapts to the curriculum of the Ministry of Religion.

The key informants in this study were the Ministry of Religion team, which included a group of lecturers from the Indonesian IRE Lecturers Association who formulated the Ministry of Religion curriculum, Road Map of IRE and IRE Teaching Books. The secondary data in this study is the Student's View of PAI Learning in Higher Education. To learn about the Implementation of Islamic Moderation in Higher Education, researchers distributed questionnaires via Microsoft Form at the end of October 2021. They were filled in by selected students who took part in Islamic moderation training in Bekasi. All of this data is processed and narrated to describe implementing Islamic Moderation through IRE Learning in Public Universities.

\section{Results and Discussion}

To find out about the Character of Moderate Muslims, the researcher examines the verses of the Quran and Hadith that discuss this matter. The researcher also observes how the formation of Moderate Muslims is carried out by implementing Islamic moderation values in Islamic Religious Education Lectures at Public Universities. 


\section{The concept of Islam related to the character of Moderate Muslims}

The word moderate is relevant to the Arabic term wasat which means middle. Islamic teachings are the essence of the wasat (teachings which have several meanings: 1) in the middle; 2) fair; and 3) the best. When associated with a religious context, it can be interpreted as an attitude or perspective in the middle of the existing extreme choices. Moderate Islam means carrying out Islamic teachings by understanding both textually and textually. It's not just textual that can make it too rigid or heeding the textual by only focusing on the contextual, making the perpetrators too liberal.

One of the verses of the Quran that confirms that Islam is the teaching of wasat \{an is QS al Baqarah: 143,

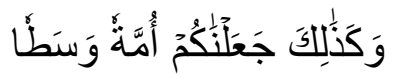

The verse above confirms that Allah made Muslims a people who have been elected and fair by not looking down on others. Another verse that directs Muslims to be able to balance their lives is seen in al-Qas $\{$ as $\{: 77$,

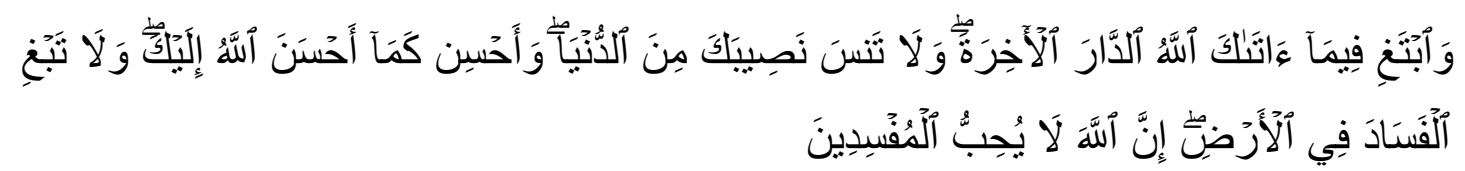

The verse above refers to Muslims balancing the life of the world and the hereafter. Also, directions to do good to anyone who gives kindness; nor do they harm the earth.

Hadiths narrated by Nasai and Ibn Majah reminded people not to overdo their behaviour that destroyed the previous people because of the attitude of going beyond the limits of religion. Several indicators indicate exaggeration in faith: 1) Fanaticism of an opinion; 2) Mandatory something that was never required in Islamic teachings; 3) Aggravating a word that is not in its place; 4) Be rude; 5) Be suspicious of others and 6) It's easy to disbelieve people who disagree with him. ${ }^{7}$

With the brief explanation above, it can be understood that the characteristics of moderate Muslims are Muslims who can understand the teachings of Islam properly and fairly; not too extreme to the right (liberal) or not too extreme to the left (conservative). Moderate Muslims are Muslims who can balance their attitudes and views.

\footnotetext{
${ }^{7}$ Fauziah Nurdin, "Moderasi Beragama Menurut Al-Qur'an Dan Hadist," Jurnal Ilmiah Al-Mu'ashirah: Media Kajian Al-Qur'an dan Al-Hadits Multi Perspektif 18, no. 1 (2021): 59-70, https://www.jurnal.arraniry.ac.id/index.php/almuashirah/article/view/10525
} 


\section{The Implementation of Islamic Moderation Values through IRE Learning}

Islamic Religious Education (IRE) Learning is a compulsory subject in Higher Education. IRE learning leads not only to individual piety; but also social piety; piety which refers to respect for oneself and others. Understanding moderate Islam is necessary; experience can balance textual and contextual awareness. Religious moderation is built on balance, justice and tolerance, which combines text and reason in making laws through the thought process of reconciling revelation and ratio. By internalizing the value of Islamic moderation, forming a Moderate Muslim becomes an expected result.

Researchers distributed questionnaires related to the Implementation of PAI Learning in General Universities to 24 students representing various Universities on the island of Java which was conducted at the end of October 2021. This questionnaire aims to find out how the Implementation of PAI Learning is based on Islamic moderation. Through the questionnaire, the following results were obtained,

\section{a. IRE Learning Model in the University}

Through the question of how the IRE learning model is implemented in the University, the responses found are as follows,

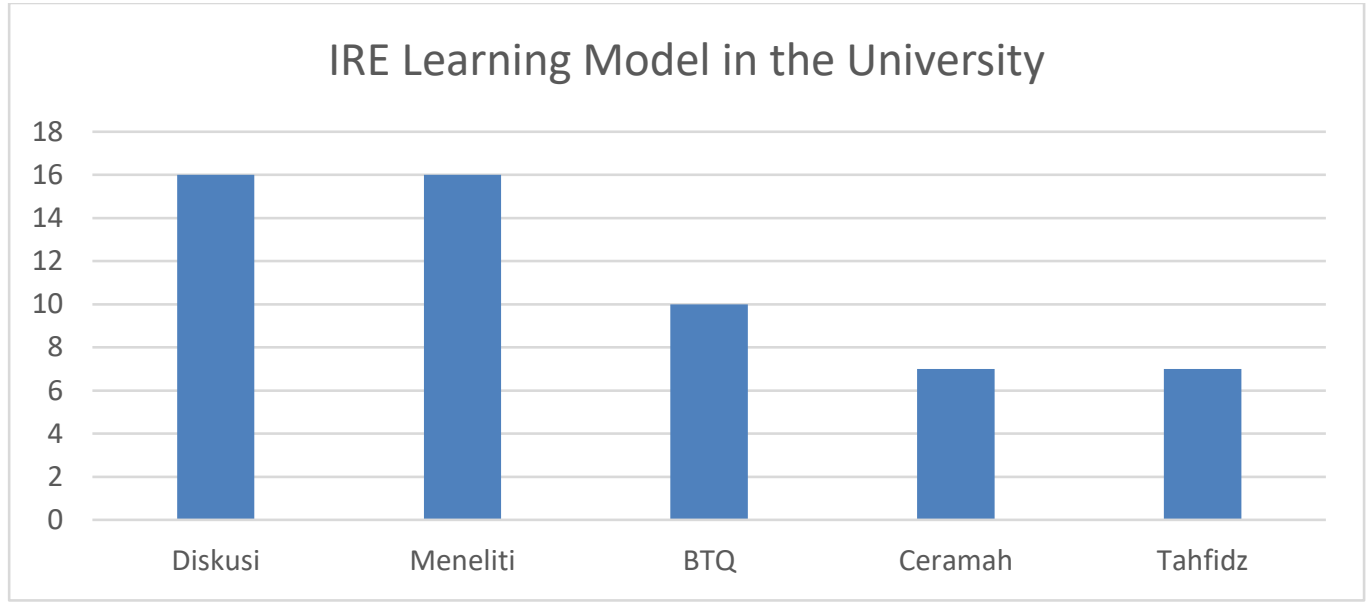

The question of this learning model refers to whether the lecturer can stimulate students with learning that makes them think analytically and can make them understand the IRE material well.

From the question of learning models, it appears that most of them have directed students to discuss and research religious phenomena around them. Several respondents revealed that IRE learning at their Universities still focuses on reading and writing the Koran and memorizing it. Several meetings with IRE lecturers acknowledged that they emphasized reading, writing, and remembering the Koran in IRE learning. They did that because there were still students who could not read 
the Koran, so they needed to be directed directly by the lecturer to be more motivated. A small number of respondents claim that lecturers still use the lecture model in IRE learning in the classroom.

The answers above illustrate that some IRE lecturers have made students analyze the material they receive and correlate it with the problems surrounding them. However, PAI lecturers still emphasize basic skills, reading and writing the Koran, which should have been studied at the previous education level.

\section{b. The Suggestions to make IRE learning more exciting and easy to understand}

This question was asked to see students' expectations so that IRE learning would be more exciting and not just a mere formality. By making IRE material attractive, students can understand religion optimally.

From this question, the answers are as follows,

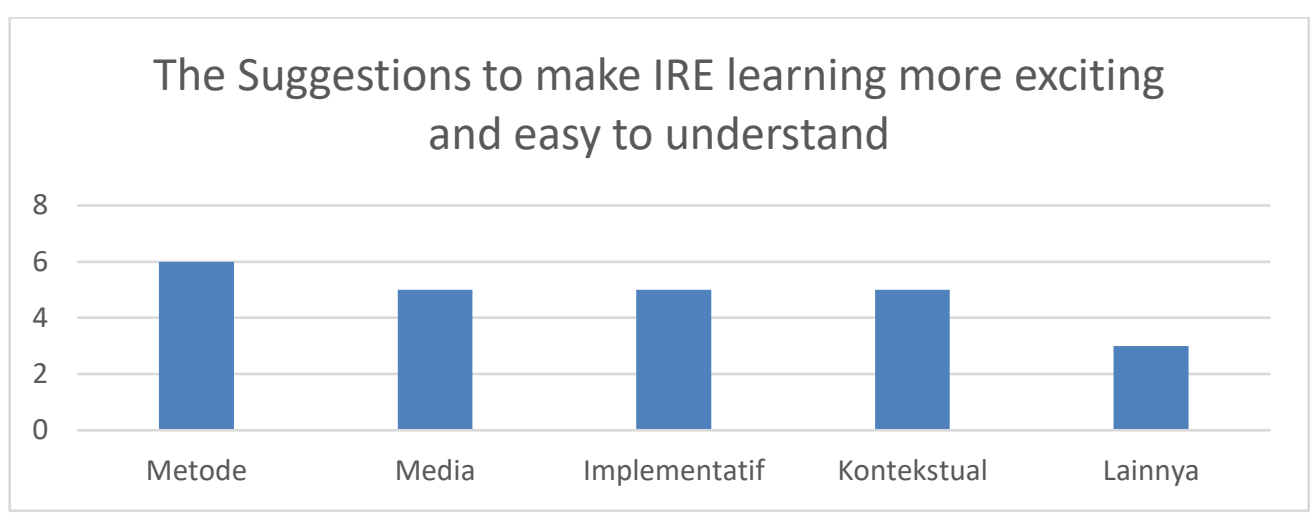

Suggestions submitted by respondents so that IRE learning becomes exciting are very diverse. Six respondents focused on learning methods that must be clear, varied and interactive; not only impressed by lectures but also expected to involve student participation. Five respondents focused on the use of media. Lecturers are expected to deliver material with sound and more attractive packaging. Lecturers are expected to be familiar with digital media, videos and even active on social media.

Ten respondents focused on learning material even though in a different direction. Five of them concentrate on usability; the material is not just a discourse but also applicable and implementable. Lecturers must make the material presented helpful in everyday life. The other five respondents focused on novelty; the material must be up to date, contextual undercurrent, actual and contemporary 
needs. Thus, lecturers are expected to relate the material to current phenomena, not material confined to the past.

Meanwhile, the other three respondents suggested that IRE learning limited in credits should complement various other religious activities. IRE learning should also have links with religious organizations on campus to become more open to spiritual insights.

\section{c. The religious activities in the Univesity}

Researchers also tried to investigate religious activities in the Univesity. This question was asked to see the variety of religious activities in the Univesity and potentially direct the direction of students' religious attitudes. The answers given are as follows,

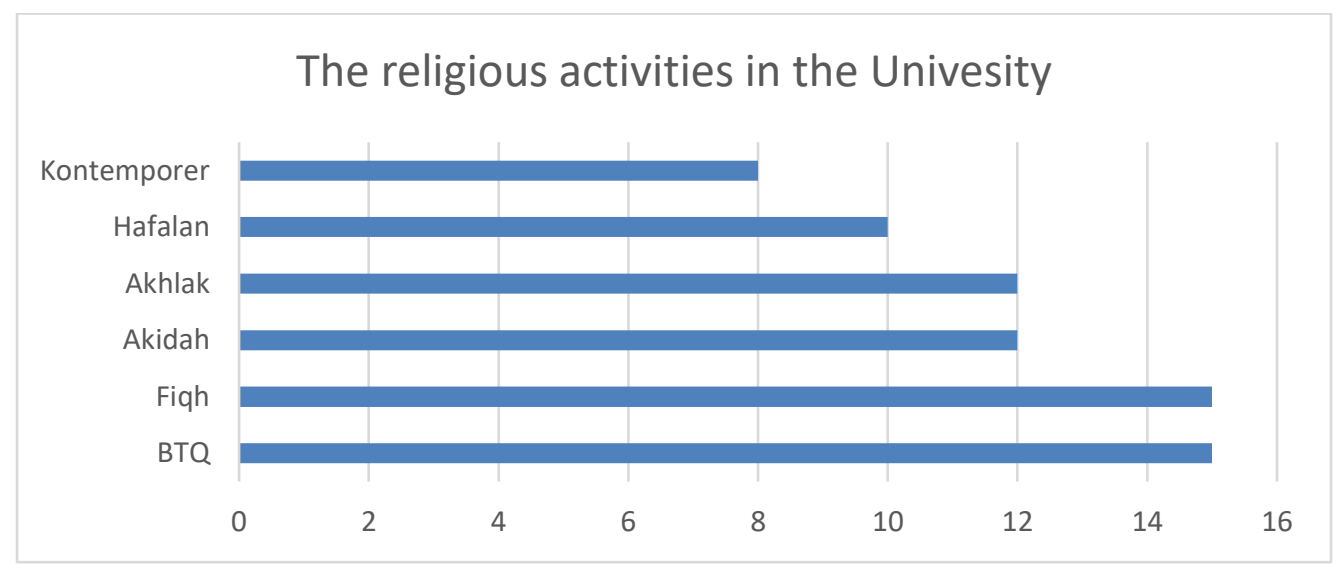

The researcher tried to trace the religious activities identified by the respondents in their Universities. The results obtained indicate that reading and writing the Koran is the most activity in several Universities; However, some Universities make it a mandatory exercise and require students to pass the IRE Course. The results show that reading and writing the Quran, which had been understood at the previous level of education, still needs to be strengthened in higher education. It seems to indicate that the ability of students to analyze and directly access the Quran as a source of Islamic teachings cannot be optimal as long as students still do not master the Reading and Writing of the Quran. On the other hand, this phenomenon shows the high enthusiasm of students to get to know the Koran without being too late.

The findings above also revealed that the systematic study of Fiqh has a higher level than other studies. Fiqh is an applicable study, which becomes a guide for Muslims in carrying out worship. 


\section{d. Things that affect religious life at University, in rating.}

The researcher also explored the students' views on things they think to affect religious life at the University. The surprising answer is as follows,

1) IRE learning in class

2) Religious Activities coordinated by the University

3) Religious activities coordinated by religious organizations in the University

4) Religious activities coordinated by organizations outside the University

5) Religious activities coordinated by LDK, Religious Institutions managed by students

The answers above indicate that PAI learning in the classroom still plays an essential role in shaping students' religious views and attitudes. Therefore, IRE learning should be the key to instilling the value of moderation in universities

\section{e. Suggestions for a more conducive religious life at the University}

The researcher also tried to ask the respondents' views on suggestions that could be made to make spiritual life in the University conducive. Most of the respondents focused on strengthening tolerance and mutual respect between followers of different religions. While other suggestions are as follows,

1) Regarding strengthening understanding

- Strengthening religious insight on social media

- Cultivating faith on campus

- Routine studies related to Islam Rahmatan Lil Alamin; Islamic teachings that are full of compassion for all creatures in the world

- Strengthening religious moderation on campus

- $\quad$ - Religious learning that is light and easy to absorb

2) Related to Policy

- Standardization of religious life at the University

- Collaboration of various parties in realizing a conducive spiritual life

3) In Strengthening Religious Organizations

- Overview of religious activities on campus

- Funding for religious activities so that they can hold more activities.

- Spiritual coaching

- More socialization of religious activities in the University 
The variety of answers above shows the respondents' concern for a conducive religious life in The University.

\section{f. The Implementation of the value of religious moderation in universities}

The researcher also tries to understand the Implementation of the value of religious moderation at the University by asking simple questions, which refer to the indicators of the value of religious moderation which the Ministry of Religion sets: 1) National Commitment, 2) Tolerance, 3) Anti-violence and 4) Accommodating to local culture. ${ }^{8}$

Regarding the indicators of national commitment, the researcher started with a simple question, the intensity of Singing the Great Indonesia Anthem in Religious Activities and Making Pancasila as the basis of the Organization's policies.

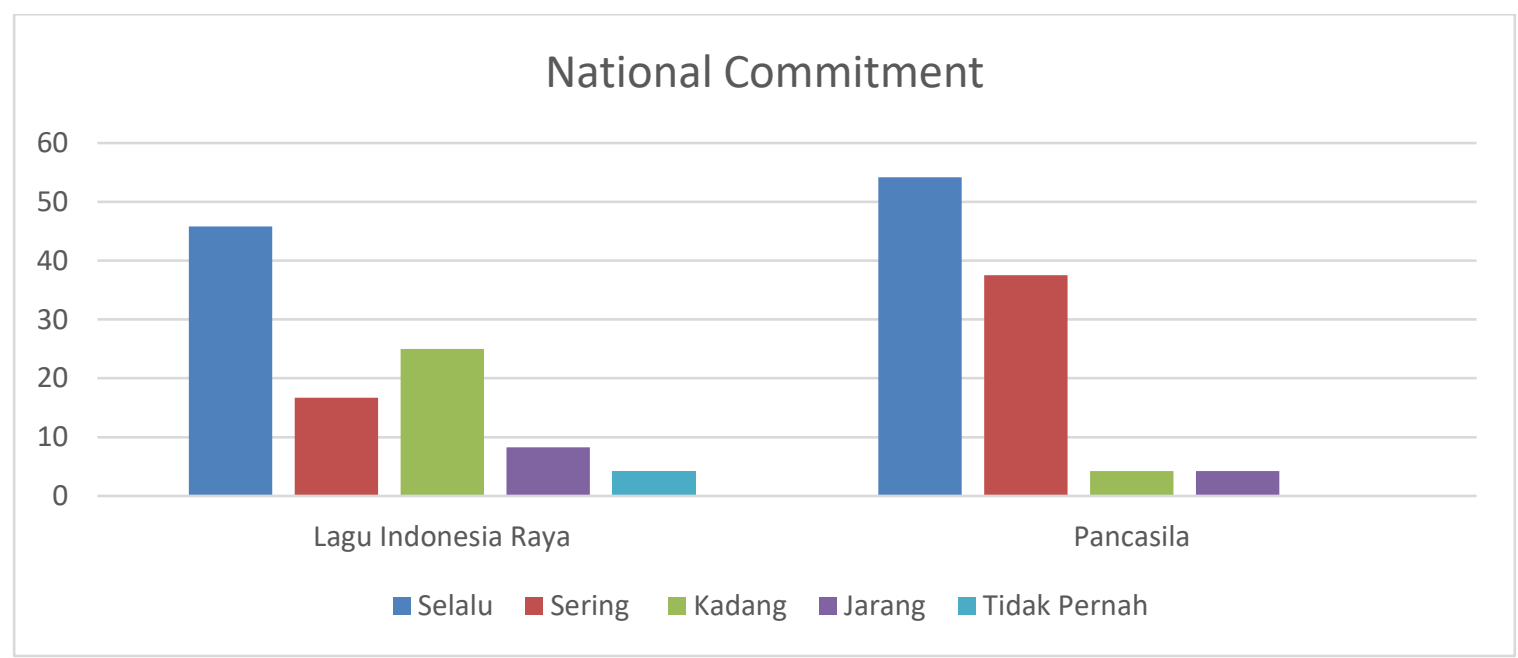

From the table above, most respondents have a pretty good national commitment in their religious activities at the University. They made the Indonesia Raya anthem as part of the opening of the religious activities and made Pancasila the basis for organizational policies.

Regarding the indicator of tolerance, the researcher traced it with simple questions, the intensity of opening events with Quran recitations in all activities, both religious and general, Considering carrying out activities on Sundays because there are non-Muslim students who carry out their worship and providing space for non-Muslim students to be able to carry out their worship

\footnotetext{
${ }^{8}$ Kementrian Agama RI, Moderasi Beragama.
} 


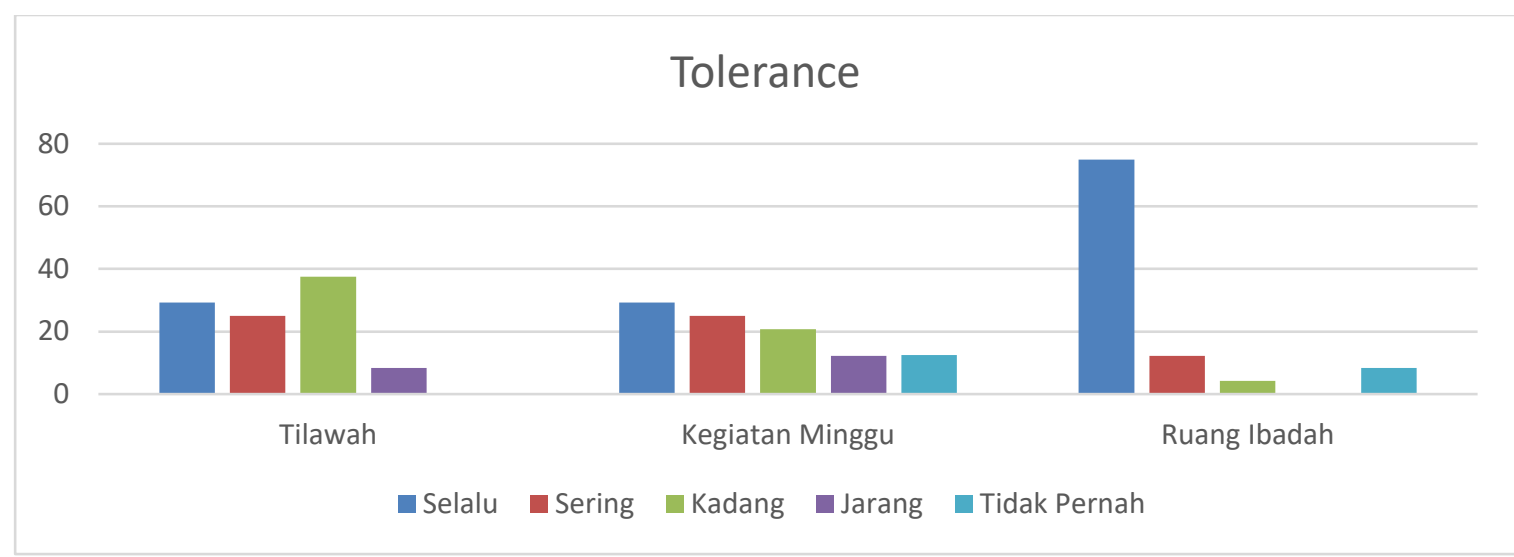

Researchers included recitations as part of the tolerance question because, on several occasions, non-Muslim students felt mistreated because of the existence of recitations in general activities. They still understand when recitations are included in a series of religious activities. They think recitations are a special ritual for Muslims and do not include non-Muslims.

Interestingly, some respondents have never considered Sundays or prayer rooms for non-Muslim students. After being traced, it turned out that the respondents came from Islamic universities which did not have non-Muslim students in them.

Regarding the anti-violence indicator, the researcher traced it with a simple question the intensity of views of believing that if someone has a different opinion with you, then that person misunderstands religion and the intensity of friction between Muslim and non-Muslim students

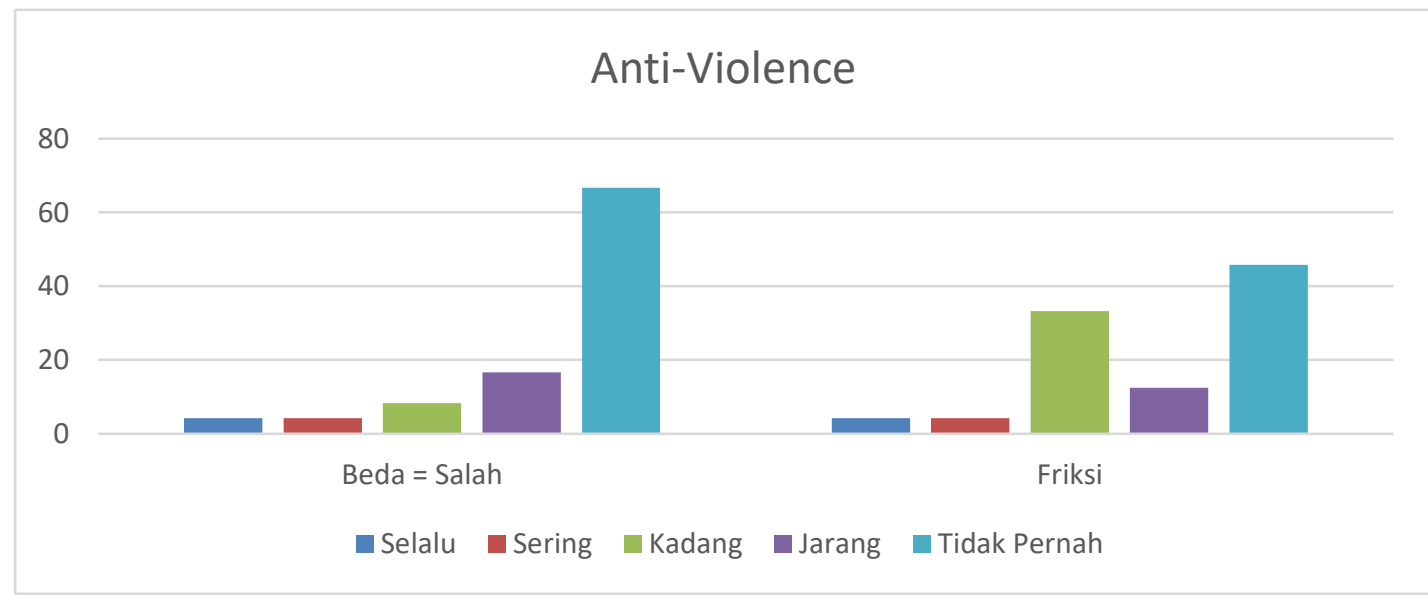

The related question when different is wrong is asked because, generally, violence begins with the belief that the other person is wrong. The majority of respondents gave positive answers by stating that they had never judged those who 
had different views. In addition, from other questions related to friction with nonMuslims, it was found that the majority stated that there was no significant friction between Muslim and non-Muslim students.

Associated with indicators of adaptive with local culture, the researcher traced it with simple questions, the intensity of directing students to use the Peci in religious activities, Requiring students to use robes and syar'i headscarves, and Carrying out the Prophet's Birthday and Tahlilan

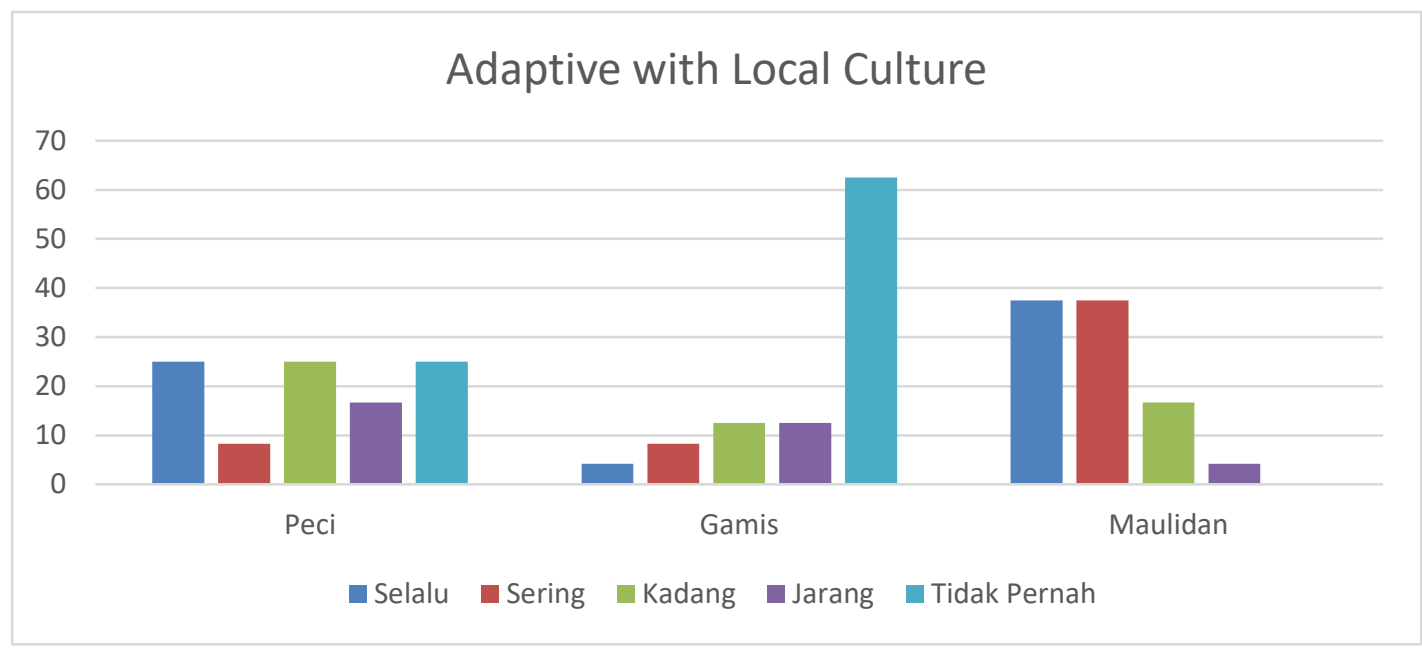

Questions related to Peci, more because Peci is synonymous with Indonesian people. However, there seems to be a balance of answers because it must be admitted, Peci is identical with Indonesia, especially Nahdhatul Ulama. Meanwhile, not all respondents are affiliated with the Nahdhatul Ulama Institution. In addition, the question of the robe is based on the robe identical to Arabic culture. The majority of respondents answered that their Universities never directed their students to dress up. On the other hand, the question of tahlil and maulid is based on the view that $\operatorname{tahlilan}^{9}$ and maulidan ${ }^{10}$ are unique to Indonesia; However, this culture is more closely related to Nahdhatul Ulama's understanding.

IRE learning at public universities is currently directed at an understanding approach to moderate Islam. There are still several things that must continue to be pursued to change the previously existing method; The method still widely implemented today is

\footnotetext{
${ }^{9}$ Tahlilan is an Islamic tradition of the Archipelago which aims to express sympathy and empathy for the families who are stricken by the accident of death.

${ }^{10}$ The tradition of Maulid Nabi is a celebration carried out in commemoration of the birthday of the Prophet Muhammad SAW as a form of the people's love for the Prophet. It is become one of the media for the spread of Islam in Indonesia
} 
still doctrinal. The current material is still a dogma that cannot be analyzed. Understanding religion with a doctrinal approach seems narrow because it is only an understanding of the past. It becomes the transcendence of religious thought, where current views are glorified not to accept new ideas.

The impacts of implementing a dogmatic curriculum include 1) students feeling bored with rigorous learning; 2) Rigid learning generally does not require student participation. IRE courses are only used as a formality for grades. 3) religious practice is only used for self-purification; only for the sake of the afterlife alone; to create a gap between the interests of the world and the hereafter; 4) religious insight becomes narrow and shallow; and 5) religious understanding becomes ahistorical; regardless of the history of its formation.

On that basis, the socialization of IRE learning with an Islamic moderation approach needs to be intensively carried out. This approach puts religious thought as its capital and makes social science and humanities its analytical knife. The IRE curriculum does not focus solely on classical and medieval tradition thought but also accommodates modern and contemporary thought development. The IRE curriculum pays attention to social realities and global needs by emphasizing the dimensions of dynamic, moderate teaching and showing the character of religion as rahmatan lil Alamin. This belief carries compassion for all nature. Faith is placed in the context of an ever-changing reality so that religion can be understood as a value, and its understanding is dynamic and responds to current conditions.

The moderate curriculum can be seen from the material discussed in IRE learning. IRE material does not only discuss basic things. But it is also correlated with current phenomena. The subject matter must be contextual. The themes discussed according to the Ministry of Religion curriculum are:

1. The concept of divinity and its implications in social life;

2. The concept of humans as divine beings;

3. The role of religion in building civilization;

4. The Koran as an inspiration for culture;

5. Sunnah as a cultural example and inspiration;

6. Ijtihad as a mechanism for contextualizing the Qur'an and Sunnah;

7. The concept of Islamic ethics and aesthetics in the development of science and technology;

8. Work ethic as a form of good deeds; 
9. Implementation of Islamic teachings in family development;

10. Performance of Islamic education in a multicultural society;

11. The Islamic concept of state and government;

12. The Islamic concept of the environment;

13. The role of religion in dealing with contemporary issues.

Implementing IRE Learning in an Islamic moderation approach also needs to be supported by Lecturer Resources as a transmitter of religious knowledge. Lecturers must be moderate and tolerant with some Indicators. Lecturers enlighten students in maintaining traditions and cultures that do not conflict with sharia, Islamic Law. Second, In solving problems for which there is no reference, secondary arguments can be used, such as qiyas, sadd dhara'i, 'urf, maslah\{ah mursalah. Third, Lecturers Use acculturation methods in adapting local culture for da'wah; Forth, Lecturers consider Maqashid Sharia or the purpose of establishing Islamic law- in the application of Islamic law and the last, lecturers enforce goodness with a wise attitude and politely forbid evil.

Submission of material should also be made with an interdisciplinary approach by integrating religious values in science. For example, when discussing Islam and the environment, it can be directed so that students can recognize their environment, including potential disasters, to be anticipated as early as possible. ${ }^{11}$

Submission of material by lecturers should also be supported by appropriate media for today's generation. ${ }^{12}$ Learning evaluation is also directed not only to emphasize the affective and psychomotor side only; but also with a sense / affective approach. Religious teachings are understood with the heart.

By strengthening the internalization of Islamic moderation values, students are expected to become moderate Muslim figures who can appreciate differences by understanding and tolerating the existence of other religions in social life. They build an attitude of understanding each other's identity and promoting positive collaboration with fellow human beings in good intention.

\footnotetext{
${ }^{11}$ Lihat lebih lanjut dalam buku PAI UNJ, Andy Hadiyanto et al., Pendidikan Agama Islam Untuk Perguruan Tinggi (Jakarta: Fikra Publika, 2020).

${ }^{12}$ Sari Narulita et al., "Religion Learning Strategies for the Z Generation," in 1st International Conference on Education Social Sciences and Humanities (ICESSHum 2019), 2019, 870-875.
} 


\section{Closing}

Islamic teachings are moderate teachings that direct followers to be fair; not only fixated on textual but also consider contextual, social and cultural. Referring to the curriculum set by the Ministry of Religion, Islamic Religious Education Learning in Higher Education has in general led to a moderate understanding of Islam which directs students to become moderate Muslim figures who can balance their attitudes and views.

A qualified IRE curriculum, high enthusiasm for learning to know the Koran and religion and supported by the ability of lecturers in directing students to be more active in contributing to life make students more optimal in implementing the values of Islamic moderation. The three main components should make students able to become figures who respect differences by understanding and tolerating the existence of other religions in social life, building an attitude of understanding each other's identity, and promoting positive collaboration with fellow human beings in good intention.

\section{E. Daftar Pustaka (Bibliography)}

Alam, Mansur. "Studi Implementasi Pendidikan Islam Moderat Dalam Mencegah

Ancaman Radikalisme Di Kota Sungai Penuh Jambi." Islamika 1, no. 2 (2017): 36.

Bruinessen, Martin van. Contemporary Developments in Indonesian Islam Explaining the "Conservative Turn. Singapore: ISEAS, 2013.

Effendi, M. R. (2020). Mitigasi Intoleransi dan Radikalisme Beragama di Pondok

Pesantren Melalui Pendekatan Pembelajaran Inklusif. Paedagogie, I (I), 55-74.

Hadiyanto, Andy, M Ridwan Effendi, Sari Narulita, and Firdaus Wajdi. Pendidikan Agama Islam Untuk Perguruan Tinggi. Jakarta: Fikra Publika, 2020.

Ismail, Y. (2019). Postmodernisme dan Perkembangan Pemikiran Islam Kontemporer. Jurnal Studi Al-Qur'an , 15(2), 235 - 248.

Ismail, Y. (2015). Pendidikan Agama Islam Berbasis Teologi Kerja. Jurnal Studi AlQur'an , 11(1), 70-81

Kementrian Agama RI, Badan Litbang \& Diklat. Moderasi Beragama. Jakarta: Kementrian Agama RI, 2019.

Laisa, Emna. “Islam Dan Radikalisme.” Islamuna 1, no. 1 (2014): 1-18.

Mushlihin, M., Narulita, S., \& Aulia, R. N. (2021). Education and the formation of Islam Nusantara: Epistemology, Direction and Sustainability. Hayula: Indonesian Journal of Multidisciplinary Islamic Studies, 5(2), 261-270.

Muttaqien, A., Hadiyanto, A., \& Mardhiah, I. (2016). Pengarusutamaan Islam Nusantara Melalui PAI dalam Perspektif Dosen PAI UNJ. Jurnal Studi Al-Qur'an, 12(1), 1-21. Narulita, Sari, Rihlah Nur Aulia, Elisabeth Nugrahaeni, Firdaus Wajdi, Izzatul Mardhiah, 
and Andy Hadiyanto. "Religion Learning Strategies for the Z Generation." In 1st International Conference on Education Social Sciences and Humanities (ICESSHum 2019), 870-875, 2019.

Nurdin, Fauziah. "Moderasi Beragama Menurut Al-Qur'an Dan Hadist.” Jurnal Ilmiah AlMu'ashirah: Media Kajian Al-Qur'an dan Al-Hadits Multi Perspektif 18, no. 1 (2021): 59-70. https://www.jurnal.arraniry.ac.id/index.php/almuashirah/article/view/10525.

NURPRATIWI, Suci; EFFENDI, Muhamad Ridwan; AMALIYAH, Amaliyah. Improving Religious Literacy Through Islamic Religious Education Course Based On The Flipped Classroom. Istawa : Jurnal Pendidikan Islam, [S.1.], v. 6, n. 1, p. 16-29, mar. 2021. ISSN 2541-0970.

Pew Research Center. The Global God Divide, 2020. https://www.pewresearch.org/global/2020/07/20/the-global-god-divide/.

Siti Julaeha, E., Ridwan Effendi, M., \& Karnafi. (2021). Everyone is Teacher Here Method and Its Effectiveness On Learning Outcomes of Akidah Akhlak. Muttaqien Publishing, 1(1), 91-104. 